\title{
Kerkvernuwing in die lig van Bybelse begrippe vir die kerk
}

\author{
J.M. Vorster \\ Dept. Ekklesiologie \& Dogmatologie \\ Hammanskraalse Teologiese Skool/PU vir CHO \\ POTCHEFSTROOM
}

\begin{abstract}
Church renewal in the light of biblical concepts of church

In the process of church renewal as a modern phenomenon in ecclesiology. three premises are important. Firstly, church renewal must always be considered in view' of a sound biblical concept of the church. Sociological factors alone are not sufficient in this regard. Secondly, paradigms for church renewal should be evaluated on the basis of a sound biblical paradigm. Thirdly, an extensive exposition of the meaning of the various biblical concepts of the church is necessary to avoid one-sidedness and distortions.

In this article the main biblical concepts of church are discussed. Special attention is paid to the relevance of each of these concepts for the renewal of the church in a modern context. The concept of the Kingdom of God as paradigm and the concepts people of God, body of Christ and the temple of the Holy Spirit are implemented as guidelines.
\end{abstract}

\section{Beginsels vir kerkvernuwing}

Die prosesse van kerkvernuwing wat tans die prominente tema in die ekklesiologie wêreldwyd is, moet oorweeg word in die lig van bepaalde kardinale beginsels. Eerstens moet gesê word dat kerkvernuwing nie losgemaak kan word van die wese, aard, historiese ontwikkeling en kenmerke van die kerk nie. 'n Blote sosiologiese benadering waardeur die kerk vernuut word volgens die eise en patrone van die moderne samelewing laat nie reg geskied aan die fundamentele Bybelse aspekte van kerkwees nie. Die gebreke van 'n suiwer sosiologiese benadering word op insiggewende wyse deur Trimp (1971:117) aangetoon. Hoe belangrik en bruikbaar sosiologiese bevindinge ook al is, kan kerkvernuwing nie uitsluitlik hiervolgens plaasvind nie.

Tweedens moet die vraag na 'n teologiese paradigma vir kerkvernuwing beantwoord word. Die paradigma bepaal die doelpunt van alle vernuwingsaksies. 
Dulles (1987:15) toon aan hoe kerkmodelle in die verlede ekklesiologiese paradigmas geword het en die kerkbeskouinge van verskeie tradisies ingrypend beinvloed het. Hierdie feit spreek ook duidelik uit die debat wat tans in Suid-Afrika oor die 'herder-kuddemodel' teenoor die 'liggaamsmodel' gevoer word, soos blyk uit die gevallestudie van Hendriks (1992:36). Die 'herder-kudde-model' as paradigma lei tot bedieningstrukture waarin die kerklike anpte sentraal staan, terwyl 'n keuse vir die 'liggaamsmodel' 'n bedieningstruktuur to gevolg het waarin alles draai om die belewing van geloofsgemeenskap. Daar is ook ander paradigmas in swang (Anderson, 1992:163). In hierdie navorsingsartikel word gekies vir die koninkryk van God as paradigma vir kerkvernuwing (Vorster, J.M. 1993:522). Die belangrikste implikasie van hierdie benadering is dat die kerk in die lig gedefinieer word as 'n teken van die koninkryk. Dit beteken dat die kerk funksioneel moet wees in die koms van die koninkryk. Kerkwees word so beplan en vernuwe binne die groter perspektief van die koninkryk.

'n Derde belangrike beginsel wat moet geld in kerkvernuwing, is die lig wat die belangrikste Bybelse beelde van die kerk oor die onderwerp bied Dulles (1987: 20) sê tereg dat die simboliek van die beelde noodsaaklik is vir die verstaan van die kerk en alle handeling wat daarmee te doen het Die openbaring van God oor die kerk kom deur verskeie Bybelse beelde aan die lig en waardevolle nuwe navorsing hieroor is onder andere gedoen deur Kung (1992:107); Gassmann (1968: 289); Tillich (1967:149); Ridderbos (1971:364) en Heyns (1977:42). Breytenbach (1992:391) gebruik ook Bybelse beelde on riglyne te trek vir gemeentebou Uit al hierdie navorsing blyk dit dat die beelde en gepaardgaande uitdrukkings belangrik is om 'n beginselbasis vir teenswoordige kerkvernuwing daar te stel. Hierdie saak word in die artikel verder ondersoek. Met die koninkryk as paradigma word dus gelet op die betekenis van die beelde vir kerkvernuwing vandag.

Die beelde van die kerk kan in drie hoofgroepe ingedeel word. Hierdie drie hoofgroepe hou verband met die drie-eenheid van God Van Genderen en Velema (1992:631) noem dit die "trinitariese" lig waarin die kerk gesien moet word. Snyman (1977:57) het in sy openbaringhistoriese behandeling van die begrip kerk ook tot die konklusie gekom dat die beelde vanuit die drie perspektiewe van die drie-eenheid van God beskrywe word. Die eerste perspektief is God die Vader. In hierdie opsig word die kerk beskryf as 'volk van God'. Die tweede perspektief is God die Seun. In hierdie opsig word die kerk beskryf as die "liggaam van Christus'. Die derde perspektief is God die Heilige Gees. In hierdie opsig word die kerk beskryf as die 'gebou van die Heilige Gees'. In die lig van hierdie drie perspektiewe word vervolgens aandag gegee aan die betekenis van die belangrikste beelde en die implikasies daarvan vir kerkvernuwing vandag. 


\section{Die kerk as volk van God}

Die uitdrukking volk van (jod het 'n Ou-Testamentiese agtergrond. Die volk van Israel is so beskrywe vanwee sy besondere verhouding met God (Deut. 14:2) wat 'n unieke wyse van lewe en diens geimpliseer het (Deut. 26:16-19). Met Israel het God sy verbond gesluit (Gen. 17) en hom afgesonder van die ander volke omdat sy volk aan Hom behoort (Lev. 20:26). Die woorde wat hiervoor gebruik is, het die 'volk van God' in die Ou Testament beskrywe as 'n kultusgemeenskap en as 'n samekoms van mense soos byvoorbeeld by Sinai (Deut. 5:22) en by die inwyding van die tempel (1 Kon. 8:22).

Küng (1992:107) is vall mening dat die Ou-Testamentiese begnip die denke oor die kerk in die Nuwe Testament beinvloed het. Die dissipels het die term op hulleself van toepassing gemaak. Teenoor die ander godsdienstige groepe soos die Esseners en Fariseërs het hulle hulleself beskou as die 'ware' en 'nuwe' Israel. Küng sien dus 'n historiese simboliese band tussen die uitdrukking in die Ou Testament en die Nuwe Testament.

Bright (1963:71) het egter vroeèr reeds aangetoon dat dit oor meer gaan as slegs 'n historiese verband. Die kerk as 'volk van God' is vir hom 'n vervulling van wat die begrip in die Ou Testament uitgedruk en beloof het. Die geskiedenis van Israel was benewens hulle gehoorsaamheid, ook dikwels 'n geskiedenis van ontrou en goddeloosheid. Tog het God telkens sy verbond met hulle bevestig. Hoewel hulle geoordeel word en uiteindelik in ballingskap weggevoer word, is daar 'n klein oorblyfsel wat hulle tot God bekeer. Hierdie oorblyfsel is in heilshistoriese, en nie net historiese sin nie, die volk van God. Ridderbos (1969:4) beskryf om dieselfde rede die volk van God in die Ou Testament as die volk wat hulle unieke bestaan en verwagting gevind het in die teokratiese regering van God. Hulle was dus die volk van God se koninkryk wat geleef het met Messiaanse heilsverwagting (Vriezen, 1966:476).

Met die koms van Christus breek die koninkryk van God deur in die harte van mense uit alle volke, tale en nasies. Hulle wat gelowig reageer op die groot genadige herskeppingsdaad van God, wat buig voor die nuwe Koning, wat die knis begryp en omhels, hulle word deur die koninkryk in besit geneem. In modene taal kan gesê word dat hulle burgers word van die koninkryk of volk van die koninkryk. Die volk van God in die Nuwe Testament is die openbaringshistoriese voortsetting van die volk van God, Israel, in die Ou Testament. Die eenheid lê in Christus en daarom word verskeie Ou-Testamentiese benaminge vir die NuweTestamentiese kerk gebruik - benamings soos: Israel (Rom. 9:6); volk (Tit. 2: 14); priesterdom (1 Pet. 2:5,9) lempel (1 Kor. 3:16), gehou (1 Kor. 3:9) en liggaam (Kol. 1:18). Ook die Middelaarsbenamings vall Clıristus dui op die voortsetting (Theron, 1978:42) 
Volgens Gassmann (1968:290) wil die beeld volk van God juis die eenheid van die ou en die nuwe verbond beklemtoon. Hierdie beeld dui daarop dat die Here sy volk in aansyn roep, lei, regeer en bewaar dwarsdeur die wêreldgeskiedenis. Hierdie versekering lê opgesluit in die beeld volk van Gơd en karakteriseer die kerk as ewig, uniek, onvernietigbaar en verhewe bo die magte van die geskiedenis. Terselfdertyd wys die beeld ook op die volk se volkome afhanklikheid van God vir bestaan en voortbestaan (Heyns, 1977:48).

Die openbaring aangaande die kerk wat deur die beeld volk van (jod belig word, word verder aangevul met ander benamings, naanlik uitverkorenes, uitgeroepenes, gelowiges en geliefdes. Elkeen beskryf 'ı besondere aspek van die volk van God en word daarom afsonderlik bespreek.

\subsection{Uitverkorenes}

Die gedagte dat God vir Hom 'n volk uit die hele mensegeslag verkies het, is 'n deurlopende tema in die Ou Testament (Tillich, 1967:142). Die fundamentele saak in hierdie verkiesing is dat dit volledig rus in God se vrye genade. Die verkiesing dui op die vrymag van God en die onmag van die mens. Die mens kan vanwee sy sondeverlorenheid nie aanspraak mak op God se genade nie. Die kerk as die uitverkorenes is dus in die eerste plek 'n uitdrukking van God se vrye genade wat saamtrek in die heil in Christus. Verder word die roeping van elke gelowige en ook die kerk in die vrye genade gefundeer. In die Bybel word die aansporing van gelowiges tot diens en lewenstoewyding aan God deurgaans gemotiveer deur die feit van God se genade waardeur Hy die volk verkies het. Hierdie perspektief is van fundamentele belang vir alle ekklesiologiese denke. Versteeg (1985:9) sê tereg dat enige besimning oor die kerk eers 'n oog moet kry vir alles wat die kruis inhou. Die kerk moet in alle opsigte besien word vanuit die heil in Christus.

Juis om hierdie rede kan die kerk nie slegs sosiologies of histories beoordeel word nie. Wie na die kerk kyk vanuit die perspektief van God se genade, moet werk met die vertrekpunt dat die kerk rus in God se verkiesing en nie 'n skepping is van mense wat slegs aan menslike willekeur uitgelewer is nie. Die kerk hoef daarom ook nie deur mense in stand gehou te word nie. Die ontstaan, bestaan en voorbestaan van die kerk lê in die genade van God waardeur Hy sy volk verkies en die heil in Christus skenk. Alle pogings tot kerkvernuwing en bedieningsbeplanning word deur hierdie openbaringsgegewe bepaal In hierdie lig gesien, kan kerkvernuwing nie beteken dat die mens met sy vernuwingsbeplanning die toekoms van die kerk in sy hand hou en die voortbestaan van die kerk so moet verseker nie. Die kerk sal voortbestaan ongeag die mens. Kerkvernuwing kan nie God se werk beheer nie, maar moet menslike gebrokenheid en sonde wat God se werk teëgaan, uitsuiwer. Kerkvernuwing moet die weë oopmak en oophou sodat God se venuwing ongehinderd kan plaasvind 
In hierdie verband is die voorwaarde wat Stott (1992:220) aan kerkvemuwing stel baie belangrik. Hy sê dat alle verandering daarop gerig moet wees om die kerk daaraan te herimner wat hy is, naamlik

the chosen and beloved people of God. his own special treasure, the covenant community to whom he has committed himself forever, engaged in continuous worship of God and in compassionate outreach to the world, a haven of love and peace, and a pilgrim people headed for the eternal city.

Die neiging wat by Cox (1967:127) en ander teoloë van sekularisasie bestaan het om die kerk dood te verklaar en die koninkryk te sekulariseer is juis die gevolg van die miskenning van die mistieke oorsprong van die kerk soos uitgedruk in die benaming $u$ uncerkorenes. Wie hiervoor nie 'n oog het nie, trek die kerk gelieel en al in by die historiese proses en moet dan aanvaar dat sy bestaan tydgebonde is en dat hy soos ander historiese menslike instellings kan uitsterf. Kerkvernuwing wat so 'n vertrekpunt kies, word 'n vermoeiende spel van sosiologiese en futurologiese teorieè, wat uiteindelik weinig hoop bied - soos die sekularisasieteologie van die sestigerjare inet sy modemistiese denke inderdaad bewys het (McGrath, 1992 132; Sinith, 1992:176).

\subsection{Ulitgeroepenes}

Die kerk word ook op enkele plekke geroepenes genoem (Rom. 1:6 en 7; 1 Kor. 1:2; Jud 1:1, Op. 17:14). Hierdie benaming is nou verwant aan die bekende Nuwe-Testamentiese woord ekklesta. Sclmidi (1968:530) is versigtig om 'n etimologiese band tussen gerocpenes en ekklesia te lê, maar gee tog toe dat in Efesiërs 5:25, 1 Timoteus 3:15 en liebreërs 12:23 die band wel in gedagle is. In die Griekse kultuurwêreld het ekklesia gedui op 'n volksvergadering en dit het waarskynlik niks te doen gehad met die uitdrukking geroepenes soos Küng (1992:82) en Hey'ns ( 1977:44) beweer nie. Die Septuagint het egter die Hebreeuse uitdrukking volk van (jod met ekklesia vertaal en hierin het die gedagte van 'byeengeroep' wel 'n rol gespeel. Die woord ekklesia moet dus nie bloot etimologies nie, maar eerder teen die agtergrond van die Ou Testament verklaar word (Bruce, 1985:196).

Volgens Ridderbos (1971:370) hang die begrip geroepenes ten nouste saam met die uitdrukking uitverkorenes wat in die vorige paragrawe bespreek is. In noue verband met die uitverkiesing moet geroepenes dus ook teen die agtergrond van die historiese verkiesing en roeping van Israel deur die Here verstaan word. Jesaja 41:9 noem Israel God se dienaar wat Hy tot Hom geroep het. (Lees ook Jes. $42: 6 ; 43: 1,45: 3 ; 48: 12 ; 51: 2$.) Met Rjdderbos se eksegese as vertrekpunt kan dus gesê word dat geroepenes impliseer dat God mense losınaak van die wêreld ell aan Hom verbind. Dieselfde teologiese betekenis kan aan die begrip in die Nuwe Testament geheg word 
Die 'losmaak van die wêreld' beteken dat die gelowiges uitgeroep is uit die 'dood van die sonde'. Dit is die primêre betekenis. Die roeping beteken dat die sondaar bevry word van die gevangenskap van die sonde; dat hy in beginsel sy onvermoë oorwin en sy gebrokenheid kan hanteer. Maar die roeping betcken ook dat hy in 'n nuwe verhouding tot God staan. Hierdie nuwe verhouding kan slegs deur Christus tot stand kom. Hy is die diepste geheim van die uitgeroepenes (Heyns, 1977:45). Die nuwe verhouding tot God bring ook 'n nuwe verhouding met ander gelowiges mee. Uitroep is dus terselfdertyd saamroep rondom Christus.

Waar die term uitverkorenes wys op die mistieke oorsprong van die kerk en die motivering vir godsdiens, wys uitgeroepenes op die besondere samestelling van die kerk. Die kerk inpliseer volgens hierdie term bevryde mense rondom Christus. Kerkvemuwing moet hierdie samestelling benadruk. Alles wat of die vryheid of die 'rondom Christus' vervang, moet geidentifiseer en verander word. Die kerkgeskiedenis bewys dat die kerk maklik deformeer tot mense wat ander saambindende faktore soos tradisie, kultuur of etniese volk soek. Die 'rondom Christus' kan ook vervang word met 'rondom ampte of historiese vorme'. Edwards (1987:297) neem tans sulke en ander verskynsels waar in Europese kerke en noem dit "the blunders of Europe's churches". Die kerke m Europa beleef volgens hom 'n identiteitskrisis en 'n gepaardgaande verlies aan betekenis ondat sekulêre faktore en historiese vorme steeds grotendeels die denke oor die kerk bepaal.

\subsection{Gelowiges}

In Efesiërs 1:1 word die begrip gelowiges gebruik om die kerk te beskryf. Die uitdrukking volg logies op die begrip uilgeroepenes: op grond van sy verkiesing roep God die mens tot Hom en die roeping moet beantwoord word met geloof. Weiser (1968:182) toon aan dat geloof in die Ou Testannent altyd beskou word as die mens se reaksie op 'n daad van God. Bultmann (1968:203) kom tot dieselfde konklusie met betrekking tot die Nuwe Testament. Die geloof is dan die positiewe antwoord van die inens op die roeping deur die evangelic (Van Genderen \& Velema, 1992:536). Deur die roeping en die gelowige antwoord daarop word die verhouding van die sondaar met God herstel. Geloof omskryf dié herstelde verhouding. Ridderbos (1971:253) vat die kem van die saak raak wanneer hy geloof die "bestaanswyse van die nuwe lewe" noem. Die kenmerk van 'n gelowige se lewe is sy verhouding met God Hierdie verhouding bepaal die kwaliteit van sy hele bestaan.

Die benaming gelowiges dui dus op die bestaanswyse van die kerk wat geweef is rondom die herstelde verhouding met God. Die verhouding met God is sentraal en daarsonder is kerkwees nie moontlik nie. Hierdie uitdrukking onderskei die kerk van alle ander sanelewingsverbande. Waar dit in menslike gemeenskaps- 
verbande gaan om dit wat die mens uit oortuiging onderskryf, gaan dit in die kerk oor die geloof wat hy bely. Die kerk bely sy lewende persoonlike gemeenskap met God. Hierdie gemeenskap met God is nie slegs 'n lewensverandering soos Tillich (1967:130) impliseer nie, maar 'n totale nuwe lewe met 'n nuwe inhoud en doel.

Enige poging tot kerkvernuwing moet begin by die diskussie rondom geloof. Die modenisme het die hele kwessie van geloof bevraagteken met die gevolg dat die rasionele denke en etiese nonne meer op die voorgrond getree het. Hiervolgens moes dit dan vir die kerk nie meer gaan oor die geloof van mense nie, maar oor hulle etiese bewussyn. In die Politieke Teologie het maatskaplike betrokkenheid van die kerk vooropgestaan en het dit sake soos geloofsbelydenis en -belewenis vervang (Fierro, 1977:207). As gevolg van hierdie verskuiwing is kerkiemuwing in die sestiger- en sewentigerjare gerig op die ombouing van die kerk tot 'n politieke instrument, waardeur etiese nomne in die modene samelewing gerealiseer moet word (Vorster, 1981:263). In die proses kon die kerk saanwerk met al die instansies wat diesclfde doel voor oë het. Die politieke aksiedrif van die Wêreldraad van Kerke is 'n direkte gevolg van hierdie konsep van kerksernuwing (Wêreldraad van Kerke, 1967:92)

Dit is waar dat kerkvernuwing uiteindelik die rol van die kerk in die wêreld moet belig, maar die saak is nie, soos die Politieke Teologie beweer, die eerste tree van kerkvernuwing nie. Die feit dat die kerk in die Bybel aangedui word as gelow' ge's, wys op die dominante plek van geloof in alles wat die kerk raak Die kerk bestaan volgens dié begrip uit mense wat getipeer word deur 'n bepaalde verhouding tot God. Hierdie verhouding moet konkreet en geestelik beleef word as persoonlike gemeenskap met God (Brienen, 1978:1). Uit hierdie belewing groei die gelowige se bestaan in die wereld. Die etiese aksie van die kerk is dus ingeplant in die belydenis en die belewenis van geloof. Kerkvenuwing moet dus allereers gerig word op die opbou van die geloof. Die kerklike bediening moet so ingerig wees dat gelowiges se verhouding inet God versterk word, sodat hulle vanuit die belewenis van hierdie verhouding venuwend in die wèreld kan optree. Kerkvernuwing moet geloofsbelewing versterk en geloofsbelewing moet 'n dinamiese Christelike lewe in die wêreld oplewer.

\subsection{Geliefdes}

Naas die uitdrukkings utverkorenes, ulgeroepenes en gelowiges word die begrip gelicfdes as beskrywing van die kerk op cnkele plekke in die Nuwe Testament gebruik (Rom 1:7; Ff. 5:1, I Tim. 6:2 en Jud. 1:20). Hoewel die uitdrukking ook nou verwant is aan die drie ander uitdrukkings wil die begrip ook, soos elkeen van die ander, 'n eie aspek beklemtoon 
Volgens Ridderbos (1959:28) belig die begrip twee sake. Eerstens bring dit God se liefde aan die orde. Die kerk word geliefdes genoem ondat dit die voorwerp is van God se liefde wat in Christus tot die mens uitgaan (Rom. 5:8). In hierdie verband druk die begrip 'n ekklesiologiese kwaliteit uit. Die kerk is die sigbare teken van God se liefde, wat in die beloftes van die evangelie verkondig word. Die bestaan van die kerk is daarom in 'n sin ook die bewys dat die beloftes waar is en dat God die werk van sy hande nie laat vaar nie. Die liefde het ook 'n bepaalde karakter want dit word "in Christus" betoon (Rom. 8:39; Joh. 3:16, 35; $10: 17 ; 15: 9 ; 17: 23-26)$.

Tweedens druk die begrip geliefdes 'n belangrike aspek van die bestaanswyse van die kerk uit. Die liefde van God moet gelowiges aanspoor tot liefde vir mekaar (Ef. 5:1); daarom word die liefde wat sy oorsprong by God het in die harte uitgestort (Rom. 5:5) en is dit 'n gawe van die Gees. Die liefde in die kerk moet 'n weerspieëling wees van God se liefde tot die mens (Pop, 1964:389). Geliefdes is dus ' $n$ beskrywing van God se liefde in Christus en van die liefde wat in die bestaan van die kerk sigbaar moet funksioneer

Soos die ander genoemde uitdrukkings oor die kerk gee die begrip geliefdes 'n baie belangrike eie direktief aan enige proses van kerkvernuwing Vemuwing in die kerk noet weë open sodat God se liefde weerspieël word en die liefde tussen gelowiges kan groei. Soos die uitdrnkking gelowiges aan kerkvernuwing die doel stel om geloofsgemeenskap te bevorder, stel geliefdes die doel om liefdesgemeenskap te bevorder. Kerkvernuwing wat hierby verbygaan, is nie meer besig met die kerk van Christus nie.

Die tweede groot perspektief op die kerk is die perspektief van God, die Seun. In hierdie verband word die kerk beskryf as liggaam van Christus. Hierdie metafoor en die ander begrippe wat daarmee saamhang, stel ook belangrike vereistes vir kerkvernuwing en daarop word vervolgens gewys.

\section{Die kerk as liggaam van Christus}

Die uitdrukking liggaam van Christus as beskrywing van die kerk word in die Nuwe Testament dikwels aangetref (1 Kor. 6:12-20; 10:14-22; 12:4-8; Kol. 1:15$20,24-27 ; 3: 15$; Ef. $1: 10,22,23 ; 2: 16 ; 4: 4-16 ; 5: 22,23$ ). Daar is wel verskillende variasies van die begrip. Romeine $12: 5$ sê byvoorbeeld dat die gelowiges almal "een liggaam in Christus en elkeen afsonderlik lede van mekaar" is. In Efesiërs 1:23 word die gemeente "sy liggaam" genoem en in Efesiërs 4:11 word die gemeente beskryf as die "liggaam van Christus". In Kolossense 1:18 word van Christus gesê dat "Hy die hoof van die liggaam (is), naamlik die gemeente". Al hierdie variasies het egter dieselfde grondbetekenis en dit is dat daar 'n noue organiese band bestaan tussen Christus en die kerk en as gevolg daarvan ook 
tussen die gelowiges onderling. Hierdie grondbetekenis lê opgesluit in die begrip liggaam.

Die woord liggaam is vir die eerste keer gevind by Homeros en is deur hom in twee betekenisse gebruik, naamlik 'n lewende liggaam en 'n dooie, lewelose liggaam, dit wil sê 'n lyk (Schweizer, 1971:1024). Die verband waarin Paulus die uitdrukking liggaam van (hristus gebruik, wys duidelik dat hy nie hier die vleeslike liggaam van Christus bedoel nie: hy wys op 'n groter entiteit. Hierdie beeldspraak was in Paulus se tyd algemeen bekend, want in hierdie betekenis is die begrip liggaam ook deur die gnosisleer, die leer van Plato oor die polis en die Stoïsynse filosofie gebruik (Du Plessis, 1962:40).

In die gnosisleer is die kosmos gesien as 'n 'liggaam' waarvan elke mens 'n deel is. Plato het die 'polis' beskryf as 'n 'liggaan' wat soos die menslike liggaam 'n goed georganiseerde geheel moet wees. Die Stoisynse filosofie het die kosmos ook beskryf as 'n liggaam wat deur 'n godheid deursuur was (MacGregor, 1959: 157). Paulus maak gebruik van hierdie beeldspraak, maar hy heg daaraan 'n totaal ander betekenis. Die 'liggaam' bestaan vir hom alleen 'in Christus'. Die gelowiges word in Christus saangevoeg tot 'n groter entteit, naamlik die 'liggaam' waarvan Christus die hoof is.

Kolossense 1:18 werp belangrike lig op die hoofskap van Cliristus: die woord wat vir 'hoof gebruik word, dui op die kop van 'n menslike liggaam. Christus is dus nie hoof van die liggaam soos wat iemand hoof van 'n skool of vereniging is nie. Perriman (1990:136) waarsku daarteen dat die begrip verklaar word vanuit so 'n moderne voorveronderstelling. Paulus gebnik die woord as aanduiding van 'n fisiologies-liggaamlike hoof. Die hoof-liggaam-verbondenheid moet dan só verklaar word: net soos die kop en die liggaam van 'n mens onlosmaaklik organies aan mekaar verbind is, so is Cliristus die hoof met die kerk sy liggaam verbind. Sonder die kop kan die liggaam nie leef of funksioneer nie. Deur die kop is die ledemate van die liggaam ook aan mekaar verbind. Dit gaan dus in die metafoor liggraam van (hristus primêr on die hegte, mistieke verbondenheid van Christus en die gelowiges as die voedingsbron van alle vorne van kerkwees (Dulles, 1987:18).

Teen die agtergrond van hierdie primère betekenis kan ook ander belangrike aksente gelê word. Cullınann (1956:108 en 123) lê klem op die feit dat Christus die primêre regecrder van die kerk is. Hierdie aspek van die hoofskap vall Christus is sedert die Refonnasie beskou as die vertrekpunt van gerefonmeerde kerkregering (Bouwmann, 1970:2). Christus as die hoof regeer die kerk deur middel van die dienste wat Hy ingestel het. In sy dogmatiese bespreking van die begrip liggaam van (.hris/us benadruk Van Niftrik (1961:270) die kerk se volkome afhanklikheid van Christus, terwyl Guthrie (1981:745) in sy verklaring veral wys op die kerk as die die volheid "van Hom wat alles in almal veruul". Die uitdrukking liggaam van ('hristus impliseer dus benewens verbondenheid ook 
Christusregering, afhanklikheid en die geestelike vitaliteit wat bestaan (en moet bestaan) juis vanweë die band tussen die hoof en die liggaam. Daarom moet die gemeente ook in Christus opgroei (Thiessen, 1990:331) en alles wat in die samekoms van die gemeente plaasvind, moet hierop gerig wees (1 Kor. 14: 26). Die verhouding met Christus kan dus beskryf word as 'n sigbare interdimensionele verhouding.

Ander Bybelse begrippe wat die metafoor liggaam van (hristus verder belig, is gemeenskap, bruid van Christus en die wynstok en die lote.

\subsection{Gemeenskap}

Die woord gemeenskap wys primêr op die gemeenskap van gelowiges in Christus (1 Kor. 1:9). Hierdie gemeenskap is die gevolg van die verlossing in Christus. Sonder Christus is die mens dood as gevolg van sy oortredings (Ef. 2:1); 'n slaaf van die onsigbare bose magte (vs. 2); uitgesluit uit die burgerskap van Israel en ver van God af (vs. 12). In Christus word die sondaar egter 'n nuwe mens en ontvang saam met Hom 'n plek in die hemel (Ef. 2:6). Christus bring uit die alleenbestaan van die sondaarmens ware gemeenskap tot stand. In hierdic nuwe gemeenskap kry die gelowige deel aan alles wat Christus het (Pop, 1964:226)

Die gemeenskap moet egter nie slegs as die mistieke gemeenskap met Christus beskryf word nie. Die gelowige se band met Christus en met sy medegelowiges moet sigbaar beleef en uitgedruk word. Sowel Van Niftrik (1961:269) as Theron (1978:119) beklemtoon die sigbare, konkrete dimensie van die gemeenskap in Christus. Die gemeenskap moet 'n sigbare en meetbare eienskap van die kerk wees, want dit lê verpligtinge op die gelowige. Die gelowige moet sy medegelowige lieflê (Heb. 13:1) en hy moet hom dien (Gal. 6:10 en Mark. 10:44). Hy moet sy medegelowige vernaan, bemoedig en ondersteun (1 Tess. 5:14, 1 Tim $4: 13 ; 2 \mathrm{Tim} .4: 2$ ). Die gelowiges word opgeroep om teenoor mekaar sonde te bely en vir mekaar te bid (Joh. 5:16) en in vrede en droefheid met mekaar saam te leef (Rom. 12:15; Ef. 4:32). Hulle moet gasvryheid teenoor mekaar bewys (Rom. 12:13) en vrede met mekaar hou (Rom. 14:19). Daar moet verdraagsaamheid (Ef. 4:2; Gal. 6:2) en vergifinis (Rom. 12:14; Ef. 4:2) wees en elkeen moet met sy naaste die waarheid spreek "want ons is mekaar se lede" (Ef. 4:25). Daar kan nog ander voorbeelde van die sigbare beoefening van gemeenskap genoem word soos Heyns (1977:90) aandui. Bogenoemde toon egter hoe belangrik die gemeenskapsbeoefening binne die liggaain van Christus is.

Die gemeenskapsbeoefening mond ook uitemdelik uit in die gemeenskaplike beoefening van Christelike kultuur binne die samelewing. Schilder (1953:76) lê 'n direkte verband tussen gemeenskap en kultuur. Op die fondament van die geloofsgemeenskap en verbondenheid van die liggaam aan die hoof vervul die gelowige sy roeping in die wêreld. Sy inspirasie vir betrokkenheid in die wêreld en 
die motivering vir sy ywer is die krag wat hy put uit sy geloofsgemeenskap met Christus as die 'kop' van 'n lewende liggaam. Die gelowige se energiebron vir sy roepingsvervulling is die gemeenskap wat hy soek en beleef in die liggaam van Christus.

\subsection{Bruid van Christus}

Die imnige verbondenleid van die kerk aan Christus word verder verduidelik deur die beskrywing van die kerk as die hruid van Christus (Op. 18:23; 21:2, 9; 22: 17). In 2 Korinthiërs 11:2 word die kerk ook vergelyk met 'n jongmeisie wat aan Christus voorgestel word en in Efesiërs 5:25 en 26 word die liefde van Christus vir die kerk teen die agtergrond van die metafoor uiteengesit. Heyns (1977:60) toon aan dat hierdie beeld wys op die eksklusiwiteit van die verhouding van Clristus en die kerk. Die trou van die Bruidegom staan vas en daarom moet die bruid weet dat sy haar liefde met niemand mag deel nie. Die beeld dui, volgens hom, ook op die 'feestelikheid' van die verhouding, want dit is 'n verhouding van vreugde en blydskap, van gemeenskap en liefde, van geborgenheid en sekerheid en van hoop en tevredenheid.

Benewens die eksklusiwiteit van die verhouding wys Gassınann (1968:221) ook op die persoonlike karakter daarvan. Die verhouding van Christus met die kerk is nie 'n verhouding met 'n korporatiewe eenheid nie, maar met elke gelowige persoonlik. Wat geld vir die kerk, geld vir elke gelowige. Ook in sy eie persoonlike lewe moet die getrouheid aan die Bruidegom na vore kom. Die persoonlike verhouding is ook die prinsipiële basis vir persoonlike etiek. Juis omdat die gelowige persoonlik aan Christus verbind is, moet hy alle seksuele losbandigheid vermy (1 Kor. 6:12-20).

\subsection{Die wingerdstok en die lote}

Hierdie beeld is deur Jesus self gebruik in Johannes 15. Twee belangrike aspekte van die verhouding van Christus en die gelowige word hierdeur uitgedruk. Eerstens word die hegtheid en intensiteit van die verhouding uitgebeeld. 'n Loot groei uit die wingerdstok; hy is deel van die wingerstok. Tweedens ontvang hy sy lewenskrag van die wingerdstok. Die loot is loot en kan vrug dra slegs as hy aan die wingerdstok verbind is. Die gelowige dra vrug en is lewenskragtig en groei in die geloof en die werke van die geloof wanneer hy soos 'n loot heg en stewig in die wingerdstok ingeplant is.

Die beeld wat Christus gebruik, wys dus op die totale verandering en die nuwe vermoëns wat die gelowige as gevolg van sy verbondenheid met Christus ervaar, maar die implikasies hiervan is ook duidelik: die loot moét in die wynstok veranker wees - dit is die diepste en belangrikste fondament van sy lewe. Buite 
Christus om is is daar geen lewenskrag, godsvrug of lewensheiliging nie (Hendriksen, 1973:300).

Die beeld liggaam van Christus en die nuwe begrippe wat dieselfde saak verduidelik, bring die proses van kerkvernuwing voor die belangrike vraag: Wie is Christus? Die antwoord op dié vraag bepaal die koers en aard van kerkvernuwing. Sowel die Teologie van Sekularisasie as die Politieke Teologie het die klem verskuif van die opgestane Christus na die historiese Jesus. Sölle (1972: 34); Gutierrez (1974:95) en Fierro (1977:15) as eksponente van hierdie verskuiwing het ook die siening van die modeme rol van die kerk verander: soos die historiese Jesus, moet die kerk ook opgaan in die stryd on politieke bevryding. Ntwasa (1973:114) druk die konsep van kerkvernuwing duidelik uit met sy stelling:

The Church, therefore cannot be seen simply as the company of believers who have had spiritual experiences. It is the company of those whose lives are perceived to have the quality of Christ-in-his-struggle-against-humanbondage. It is the company of liberators, or it is not the Church

Wie Christus bely as die opgestane Here sal kerkvenuwing totaal anders definieer. In die lig van hierdie belydenis moet kerkvernuwing gerig wees op die herstel en opbou van die idees wat die metafoor liggaam van (hristus bied. Samevattend kan die idees soos volg gestel word kerkvermuwing impliseer die herstel en opbou van die Christusregering in die kerk, die uitdrukking van interdimensionele en sigbare geloofsgemeenskap en die opbou van die voortdurende lewensheiliging en godsurug wat daaruit moet voortvloei. Kerkvernuwing moet die oog weer vestig op die lewende, verheerlikte Christus en wat daannee saamhang.

Die derde perspektief in die trinitariese lig op die kerk in die Bybel is die beskrywing van die kerk as gebou van die Heilige Gees. Om verdere prinsipiële riglyne vir kerkvenuwing uit te spel word ook aan hierdie beeld en ander gepaardgaande beelde aandag gegee.

\section{Die kerk as gebou van die Heilige Gees}

Op verskeie plekke in die Nuwe Testament word die kerk genoem "'n gebou van God" (1 Kor. 3:9; 2 Kor. 6:16; Ef. 2:20-22; 1 Tim. 3:15). Christus is die hoeksteen van die gebou (Matt. 16:18; 1 Kor. 3:11; 1 Pet. 2:6) en woon daarin deur die Gees (1 Kor. 3:16;6:19). Die gelowige beoefen ook priesterlike diens in die 'gebou' soos blyk uit die agtergrond van Hebreèrs 13:15; 1 Petrus 2:9 en Openbaringe 1:6 (Thiessen, 1990:311). Die beelde het twee belangrike fokuspunte, naamlik dat dit die kerk enersyds beskryf as woonplek van die Gees en andersyds as werkplek van die Gees. 


\subsection{Die kerk as woonplek van die Gees}

Hierdie aspek wat in Efesiërs 2:19-22 belig word, het 'n Ou-Testamentiese agtergrond. Die tabemakel in die Ou Testament was simbool van God se teenwoordigheid onder die verbondsvolk. Toe die tabenakel ingeuy is, het 'n wolk die tent oordek: "... en die magtige teenwoordigheid van die Here het die tabenakel gevul" (Eks. 4:34 en 35). Die tent het saam met die volk getrek en is later in Kanaän in verskillende vonne gevestig totdat die betekenis daarvan oorgedra is op die tempel in Jerusalem (De Vaux, 1988:312). Dit het egter mie beteken dat die Here net tot die gebou beperk was nie: die gebou was simbool van sy teenwoordigheid en van sy dinamiese regering oor die volk (Helberg, 1980:127, Vriez.en, 1966:388).

In die Nuwe Testament word die gelowige, maar ook die gemeenskap van gelowiges, voorgestel as die woonplek van die Gees, hoewel Hy nie net tot hierdie woonplek beperk is nie (Guthrie, 1981:748). Hierdie inwoning van die Gees is ' $n$ teken van die volle erfenis wat daar vir die kinders van die Here wag. In die teenwoordigheid van die Gees spreek iets van die aard van die toekomstige koninkryk van (jod (Rom. 8:23, 2 Kor 1:22). Dit beteken egter nie dat slegs 'n deel val die Gees teenwoordig is nie; ly is self volledig teenwoordig (Theron, 1978: 87). As sodanig is die kerk self ook teken van die volheid wat kom. Die kerk, vervul met die Gees, is in die hede 'n sigbare vooruitskouing van die bedeling wat eenmaal met die wederkons van Cliristus gevestig sal word. "The Spirit represents part of the future that is already present" (Cullmann, 1956:117).

Die inwoning van die Gees kwalifiseer ook die uniekheid van die kerk en hierdie uniekheid lê opgesluit in die woord heılıg. Die kerk is heilig, dit wil sê, anders as die gebroke wêreld. Selfs in sy eie gebrokenheid is die kerk nog uniek woonplek van die Gees want "distorted Spirit is still Spirit" (Tillich, 1967:375). Maar juis vanwee sy heiligheid moet dit wat wêrelds is uit die kerk geweer word en moet alles "geestelijk toegaan" (Van Genderen \& Velema, 1992:620). Die kerk kan dus nie gedefinieer word as 'n menslike instituut wat as samelewingsverband tussen ander bestaan nie. Ook is die kerk nie onderhewig aan slegs historiese en sosiologiese norme nie. Die kerk as woonplek van die Gees bestaan op ' $n$ unieke wyse. Kerkvernuwing kan daarom nie slegs uitgaan van sosiologiese nonne nie.

\subsection{Die kerk as werkplek van die Gees}

Die kerk is volgens die beeld gehon van die Heilige (jees ook die werkplek van die Gees, hoewel die werk van die Gees ook nie net tot die kerk beperk moet word nie. Die werk van die lleilige Gees word in hierdie artikel nie volledig behandel nie. Goeie eksegetiese, openbaringshistoriese en dognatiese uiteensettings vanuit gereformeerde perspektief word hieroor gevind in die publikasie van Floor (1979:63); Kruger (1981:33) en Ridderbos (1971:479). In die volgende 
standpuntstelling oor die werk van die Gees in die kerk word by hulle konklusies aangesluit.

Wanneer die werk van die Heilige Gees ekklesiologies beskou word, kan die volgende gesê word: die werk van die Gees in die kerk is on die kerk self op te bou (Du Preez, 1990:257). Teen die agtergrond van die reeds besproke beeld liggaam van Christus wys hierdie opbou ook op die dinamiek van kerkwees. Juis omdat die Gees die kerk voortdurend opbou, kan (en mag) die kerk nooit verstar in formalisme en institusionalisme nie. Organisasie en beplanning is instrumenteel in die bouprosesse en juis ondat die opbou 'n proses is, kan historiese modelle van kerkwees nie as nonnatief vir alle omstandighede aangebied word nie. Wie die kerk en bediening beskou as 'n onveranderbare, historiese model, fundeer die kerk by implikasie in die mens en daardeur word die bouproses effektief teengewerk. Wie bely dat die kerk alleen moontlik is as gevolg van die Gees (Van Niftrik, 1961:266), sal aanvaar dat die opbou van tyd tot tyd nuwe bedieningsmodelle lewer wat in diens staan van die bouproses.

Die werk van die Gees in die opbou van die kerk is egter nie willekeurig nie, die Gees bou op die fondament van die apostels en profete met Christus as die hoeksteen (Ef. 2:20). Hierdie uitdrukking vat die totale funksionering van die kerk saam. Van Niftrik (1961:265) sê met verwysing na Handelinge 2 dat die "bou op die fondament van die apostels en profete" wys op die konkrete getuienis wat in die kerk moet leef en van die kerk moet uitgaan. Hierdie getuienis is die onveranderbare permanente goue draad deur sy bestaan. Die getuienis het ook 'n duidelike konsentrasiepunt en dit is Clristus; daarom word hy die hoeksteen genoem. Met so 'n bouplan werk die Gees en wat hy in die kerk laat gebeur, is bedoel om getuienis te bewerk; daarom is kerk en getuienis feitlik sinoniem. Die getuienis moet nie net tot die prediking beperk word nie.

Van Niftrik sê verder dat die getuienis sowel die bediening van die sakramente as die beoefening van barmhartigheid bevat Getuienis impliseer 'n getuienis met Woord, aanbidding en daad en in alles wat hieruit voortvloei, moet die evangelie van Christus sentraal staan. Hoewel die bouwerk van die Gees nie in historiese modelle gegiet kan word nie, geskied dit altyd op die fondament van Christus en die Woord. Hierdie prinsipiële lyne moet in enige poging tot kerkvernuwing die rigting aanwys, want dan word die kerk vernuwe om in prediking, sakramente en barmhartigheid beter te getuig. Die bediening in al sy fasette het dus 'n globale missionêre gerigtheid

\section{Konklusie}

Die Bybelse beelde van die kerk wat die kerk in trinitariese lig beskryf, toon aan hoe groots en diep die hele openbaring aangaande die kerk is. Wie met die kerk besig is, is besig met ' $n$ bo-menslike en bo-historiese grootheid, hy is besig met 
God se werk. Heyns (1989:441) benadruk die omvattenheid van die kerk wanneer hy die kerk omskryf as 'n belydende gemeenskap, 'n aanbiddingsgemeenskap, 'n onderrigtende gemeenskap, 'n kulties-liturgiese gemeenskap, 'n profetiesgetuiende gemeenskap en 'n sendingbedrywende gemeenskap. Kerkvernuwing moet daarom in die gees van beskeidenheid geskied. Nooit kan die ekklesioloog beweer dat hy klaar gedink het oor God se kerk nie. Verder kan kerk en bedieningsmodelle wat vanuit een Bybelse beeld, byvoorbeeld of die 'herder-kudde'model, of die 'liggaamsmodel' gedefinieer word, nie aangebied word as die enigste en suiwerste model nie. Kerkvenuwing moet met al die aksente van kerkwees werk.

Die uitdrukking volk van God sê dat die kerk God se eiendom is, en nie 'n menslike instelling wat deur mense in stand gehou moet word nie. Die beeld sê ook dat persoonlike geloofsgemeenskap met God die diepliggende voorvereiste is van kerkwees. Kerkvernuwing moet hierdie beginsel eerste op die agenda plaas. Die beeld liggaam van ( hrisius belig die noodsaak van die Christusregering in die kerk en die sigbare gemeenskap van die gelowiges as kenmerke van die kerk. Kerkvernuwing kall daarom ook nie anders as on die Christusregering en gemeenskap van die Heilige Gees in enige gegewe onstandigheid te kontekstualiseer nie. Die beeld gehou van die (jees toon aan dat die kerk 'n groeiende gemeenskap is wat in alle aspekte van kerkwees van Christus en sy betekenis vir die wêreld moct getuig. (jeloofsgemeenskap met God. (hristusregering. gemeenskap en roepinggsvervulling is die pylers waaraan kerkmodelle, hediening en kerkvermusing getoets moet word.

In ooreenstemming met die wyse waarop hierdie pylers kerkvernuwing steun en rig, moet vernuwing in prediking, aanbidding, gemeenskapsbelewing, kerklike getuienis, diensbetoon, kerkregering en ekumene oorweeg word.

\section{Bibliografie}

ANDERSON, L. 1992 A Church for the 21 st Century Minneapolis : Bethany House Publishers

BREYTENBACH, HS 1992 Metafore vir die kerk en riglyne vir gemeentebou Nederdinirse Gereformeerde Teologgiese Tydskrif, 33(3) 391-407

BRIENEN, T 1978 Bevinding, aard en funktie van de geloofsbelewing Kampen J H Kok BRUCE, F E 1985. New Testament History Hants Pickering and Inglis

BOUWMANN, H 1970 Gereformeerd Kerkrecht Het recht der kerken in de praktijk Kampen : J H Kok

BRIGHT, J 1963 The Kingdom of God New York: Abingdon Press

BULTMANN, R 1968 The "Pistis" Group in the New Testament (In Kittel G ed Theological Dictionary of the New Testament Volume 6 Grand Rapids W B Eerdmans p. 203-228)

COX, H 1967. De stad van de mens, het levenspatroon van de moderne wereld in theologisch perspectief Utrecht Ambo Boeken

CULLMANN, O 1956 The Early Church London SCM Press 
DE VAUX, R 1988 Ancient Israel Its Life and Institutions London: Darton, Longman and Todd.

DULLES, A. 1987. Models of the Church New York : Double Day

DU PLESSIS, I J 1962 Christus as hoof van kerk en kosmos 'n Eksegeties-teologiese studie van Christus se hoofskap veral in Efesiers en Kolossense. Groningen. VRB

DU PREEZ, J 1990 Besinning oor die verhouding tussen gemeentebou en sending Nederduitse Gereformeerde Teologiese Tydskrif, 31(2) 257-263

EDWARDS, DL 1987. The Futures of Christianity London: Hodder and Stoughton

FIERRO, A 1977. The Militant Gospel An Analysis of Contemporary Political Theologies. London: S.C.M. Press

FLOOR, L. 1979. Hy wat met die Heilige Gees doop. Pretoria : N G Kerkboekhandel

GASSMANN, B 1968. Ecclesia Reformata Die Kirche in den Reformierten BekenntnisSchriften. Freiburg : Herder.

GUTHRIE, D 1981. New Testament Theology. Leicester : Inter-Varsity Press

GUTIERREZ, G. 1974 A Spirituality of Liberation ( $/ n$ Kee, A A Reader in Political Theology London: S.C.M Press p 95-100)

HELBERG, J.L 1980. Die Here regeer, openbaringslyne deur die Ou Testament Pretoria N G Kerkboekhandel

HENDRIKS, J 1992. Gemeentes vertel Verandering in 'n Christelike geloofsgemeenskap Kaapstad : Lux Verbi

HENDRIKSEN, W 1973. The Gospel of John. London The Banner of Truth Trust

HEYNS, J A 1977. Die kerk Pretoria : N G Kerkboekhandel

HEYNS, J.A. 1989. Die sendinggerigtheid van die kerk Nederduntse Gereformeerde Teologıese Tydskrif, 30(4) 44!-447, September

KRUGER, M.A 1981 Die Heilige Gees wat lewend maak Pretoria Die skrywer

KUNG, H 1992 The Church Kent Burns and Oates

MacGREGOR, G 1959 Corpus Christi The Nature of the Church according to the Reformed Tradition London Macmillan and Company

McGRATH, A.E 1992 Bridge-building Effective Christian Apologetics Leicester Intervarsity Press

NTWASA, S 1973. The Concept of the Church in Black Theology ( $/ /$ Moore, B ed The Challenge of Black Theology in South Africa VSA, Atlanta: John Knox Press p 109 118.)

PERRIMAN, A 1990 'His Body, Which is the Church ' Coming to Terms with Metaphor. The Evangelical Quarterly, 52(2): 123-142

POP, F J 1964 Bijbelse woorden en hun geheim, verklaring van een aantal Bijbelse woorden s'Gravenhage Boekencentrum, N V

RIDDERBOS, H 1959. Romeinen Kampen J H Kok

RIDDERBOS, H 1969 The Coming of the Kingdom Philadelphia : The Presbyterian and Reformed Publishing Company

RIDDERBOS, H 1971. Paulus Ontwerp van zijn theologie Kampen JH Kok

SCHILDER, K 1953 Christus en cultuur Franeker T Wever

SCHMIDT, KL 1968 Ekklesia (III Kittel, G ed Theological Dictionary of the New Testament Michigan/Grand Rapids : Eerdmans 3:501-536)

SCHWEIZER, E 1971. Sooma (In Friedrich G ed Theological Dictionary of the New Testament Grand Rapids: W B Eerdmans 7:1024-1044)

SMITH, D L 1992 A Handbook of Contemporary Theology Tracing Trends and Discerming Directions in Today's Theological Landscape Wheaton Bride Piont

SNYMAN, W J 1977 Nuwe en ou dinge uit die skat van die Koninkryk Pro Rege Potchefstroom 
SÖLLE, D 1972. Politieke theologie, discussie met Rudolf Bultmann Baarn : Bosch \& Keuning

STOTT, JR W 1992. The Contemporary Christian An Urgent Plea for Double Listening Leicester : Inter-Varsity Press

THERON, P F 1978 Die ekklesia as kosmies-eskatalogiese teken - Die eenheid van die kerk as "profesie" van die eskatalogiese vrede Pretoria : N.G Kerkboekhandel

THIESSEN, H C 1990 Lectures in Systematic Theology Grand Rapids : W B Eerdmans

TILLICH, P 1967. Systematic Theology Chicago The University of Chicago Press

TRIMP, C. 1971. De dienst van de mondige Kerk, een confrontatie, met het appel van de mondige wereld. Goes: Oosterbaan \& Le Cointre N V

VAN GENDEREN, J \& VELEMA, W.H 1992. Beknopte Gereformeerde Dogmatiek Kampen J.H Kok.

VAN NIFTRIK, G C 196I Kleine dogmatiek Nijkerk C F Callenbach

VERSTEEG, JP. 1985. Kijk op de kerk. De struktuur van de gemeente volgens het Nieuwe Testament Kampen : J.H Kok

VORSTER. JM 1981 Die kerk en die kleurvraagstuk vandag Johannesburg De Jongh Uitgewers

VORSTER, J M 1993 Die koninkryk van God as paradigma vir kerkvernuwing Nederdunse (jercformeerde Teologiese Tydskrif. 34 522-531. Desember

VRIEZEN, T C 1966 Hoofdlijnen der Theologie van het Oude Testament Wageningen $H$ Veenman en Zonen

WEISER, A 1968 Faith The Old Testament Concept (I/I Kittel, G e a Theological Dictionary of the Old Testament Volume VI Michigan, Grand Rapids W B Eerdmans p. 182-202.)

WÊRELDRAAD VAN KERKE 1967 Christians in the Technical and Social Revolutions of Our Time World Conference on Church and Society Geneve. July 12-26, 1966 The official report Geneve: W R K 
